\title{
Ulcerative colitis-induced myocarditis
}

\author{
Barbara Gruenhagen, M Chadi Alraies, Kairav P Vakil, Shamane K March
}

Department of Cardiology, University of Minnesota, Minneapolis, Minnesota, USA

\section{Correpondence to}

Dr M Chadi Alraies, alraies@hotmail.com

Accepted 23 April 2014
To cite: Gruenhagen $B$, Alraies MC, Vakil KP, et al. BMJ Case Rep Published online: [please include Day Month Year] doi:10.1136/ bcr-2014-204818

\section{DESCRIPTION}

A 24-year-old man presented with a $2 \mathrm{~h}$ history of substernal chest pain radiating to both arms with associated dyspnoea, diaphoresis and dizziness. $\mathrm{He}$ also reported a 3-week history of abdominal cramping with multiple loose bloody bowel movements. His vital signs were stable and general examination was unremarkable. He had similar abdominal symptoms about 3 months prior for which he sought medical attention and was given a preliminary diagnosis of colitis but never followed up. A chest CT scan was performed and ruled out pulmonary embolism. A 12-lead ECG revealed J-point ST elevation in the inferolateral leads, and cardiac troponin-I was elevated at $0.211 \mu \mathrm{g} / \mathrm{L}$ (ref $<0.034$ ). Cardiac catheterisation revealed normal coronary arteries and left ventricular systolic function. Troponin-I levels peaked at $12 \mathrm{~h}(1.57 \mu \mathrm{g} / \mathrm{L})$, then trending down the following day. Given the clinical presentation and ECG changes in the setting of normal coronary angiography, a diagnosis of acute myocarditis was suspected. Cardiac MRI showed myocardial oedema with delayed gadolinium enhancement in the subepicardial apical inferior (figure 1, left panel) and mid-apical inferolateral myocardial segments (figure 1, right panel) consistent with acute myocarditis. ${ }^{1}{ }^{2}$ Given the history of altered stool consistency and frequency, he also underwent a flexible sigmoidoscopy that showed active ulcerative colitis. Daily oral prednisone and mesalamine therapies were instituted which led to resolution of both cardiac and gastrointestinal symptoms. ${ }^{3}$ At a 1 -month clinic follow-up, the patient reported no cardiac or abdominal symptoms.

\section{Learning points}

Myocarditis is a common, but underdiagnosed disease due to its inconsistency in presentation.

- Careful workup of young patients presenting with myocarditis is warranted especially for systemic inflammatory disorders including IBD. ${ }^{12}$

- Control of the underlying disease is often associated with myocarditis resolution and prevention of recurrence. ${ }^{3}$

\section{Competing interests None.}

Patient consent Obtained.

Provenance and peer review Not commissioned; externally peer reviewed.

\section{REFERENCES}

1 Aretz HT, Billingham ME, Edwards WD, et al. Myocarditis. A histopathologic definition and classification. Am J Cardiovasc Pathol 1987;1:3-14.

2 Varnavas VC, Reinsch N, Perrey M, et al. Recurrent lymphocytic myocarditis in a young male with ulcerative colitis. Eur J Med Res 2014;19:11.

3 Kristensen KS, Hoegholm A, Bohr L, et al. Fatal myocarditis associated with mesalazine. Lancet 1990;335:605.
CrossMark

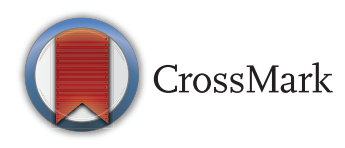

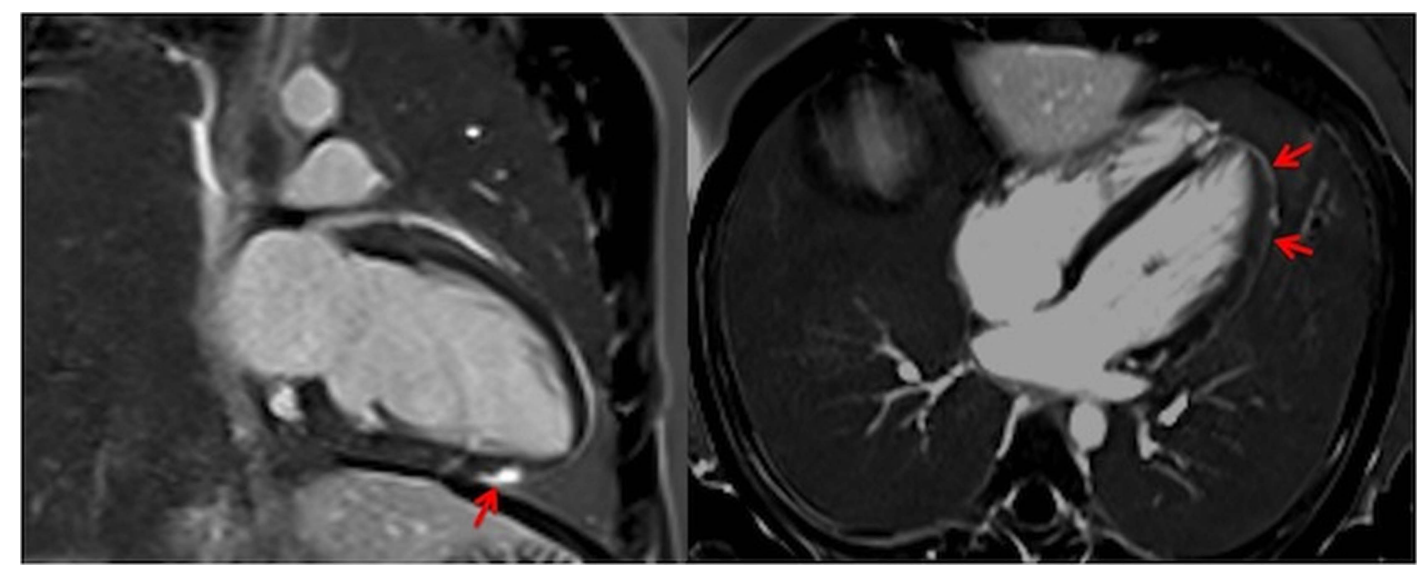

Figure 1 Cardiac MRI showing myocardial oedema and delayed gadolinium enhancement in the subepicardial apical inferior (left panel) and mid to apical inferolateral myocardial segments (right panel). 


\section{Images in...}

Copyright 2014 BMJ Publishing Group. All rights reserved. For permission to reuse any of this content visit http://group.bmj.com/group/rights-licensing/permissions.

BMJ Case Report Fellows may re-use this article for personal use and teaching without any further permission.

Become a Fellow of BMJ Case Reports today and you can:

- Submit as many cases as you like

- Enjoy fast sympathetic peer review and rapid publication of accepted articles

- Access all the published articles

- Re-use any of the published material for personal use and teaching without further permission

For information on Institutional Fellowships contact consortiasales@bmjgroup.com

Visit casereports.bmj.com for more articles like this and to become a Fellow 